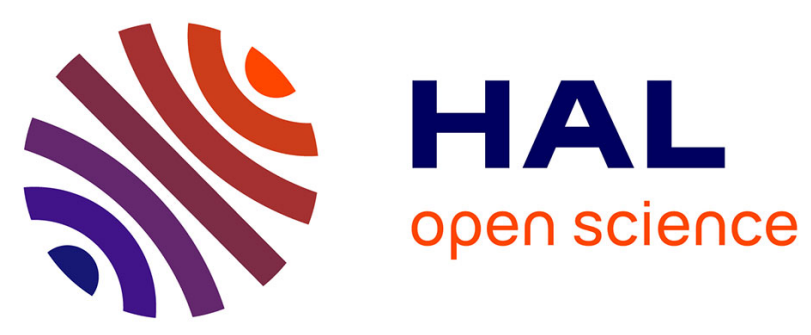

\title{
Monitoring mechanical stimulation for optimal tendon tissue engineering: a mechanical and biological multiscale study
}

Alejandro Garcia Garcia, Jean-Baptiste Perot, Megane Beldjilali-Labro, Quentin Dermigny, Marie Naudot, Sophie Le Ricousse, C. Legallais, Fahmi Bedoui

\section{To cite this version:}

Alejandro Garcia Garcia, Jean-Baptiste Perot, Megane Beldjilali-Labro, Quentin Dermigny, Marie Naudot, et al.. Monitoring mechanical stimulation for optimal tendon tissue engineering: a mechanical and biological multiscale study. Journal of Biomedical Materials Research Part A, 2021, 10.1002/jbm.a.37180 . hal-03029652

\section{HAL Id: hal-03029652 https://hal.science/hal-03029652}

Submitted on 28 Nov 2020

HAL is a multi-disciplinary open access archive for the deposit and dissemination of scientific research documents, whether they are published or not. The documents may come from teaching and research institutions in France or abroad, or from public or private research centers.
L'archive ouverte pluridisciplinaire HAL, est destinée au dépôt et à la diffusion de documents scientifiques de niveau recherche, publiés ou non, émanant des établissements d'enseignement et de recherche français ou étrangers, des laboratoires publics ou privés. 


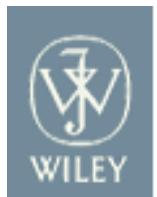

Journal of Biomedical Materials Research Part A

\section{Monitoring mechanical stimulation for optimal tendon tissue engineering: a mechanical and biological multiscale study}

\begin{tabular}{|r|l|}
\hline Journal: & Journal of Biomedical Materials Research: Part A \\
\hline Manuscript ID & JBMR-A-20-0611 \\
\hline Wiley - Manuscript type: & Original Article \\
\hline Author: & 07-Sep-2020 \\
\hline Complete List of Authors: & $\begin{array}{l}\text { Garcia, Alejandro; Sorbonne Université, mechanical engineering } \\
\text { Perot, Jean-baptiste; Compiegne University of Technology, Biomechanics } \\
\text { and Bioengineering } \\
\text { Beldjilali-Labro, Megane; Compiegne University of Technology, } \\
\text { Biomechanics and Bioengineering } \\
\text { Dermigny, Quentin; Compiegne University of Technology, Biomechanics } \\
\text { and Bioengineering } \\
\text { Le Ricousse, Sophie; Université de Picardie Jules Verne, EA7516 } \\
\text { CHIMERE } \\
\text { Legallais, Cécile; Compiegne University of Technology, Biomechanics and } \\
\text { Bioengineering } \\
\text { Naudot, Marie; Université de Picardie Jules Verne, EA7516 CHIMERE } \\
\text { Bedoui, Fahmi; Sorbonne Université, mechanical engineering }\end{array}$ \\
\hline Keywords: & $\begin{array}{l}\text { Electrospinning, Mechanical stimulation, Stem cells, Tissue engineering, } \\
\text { tendon }\end{array}$ \\
\hline & \\
\hline
\end{tabular}

\section{SCHOLARONE ${ }^{m}$ Manuscripts}




\section{Monitoring mechanical stimulation for optimal tendon tissue engineering: a}

4 Garcia Garcia A. ${ }^{1}$, Perot JB. ${ }^{1}$, Beldjilali-Labro M. ${ }^{1}$, Dermigny Q. ${ }^{1}$, Naudot M. ${ }^{2}$, Le Ricousse $5 \quad$ S. ${ }^{2}$, Legallais C. ${ }^{1}$, Bedoui F. ${ }^{3, *}$

$6 \quad{ }^{1}$ CNRS, UMR 7338 Laboratory of Biomechanics and Bioengineering, Sorbonne Universités, 7 Université de Technologie de Compiègne, 60200 Compiegne, France

8 2 EA4666-LNPC-Immunologie Therapie Cellulaire Hématologie Cancers, CURS, Hopital 9 Sud Avenue René Laennec, 80054 Salouel, France

${ }^{3}$ FRE CNRS 2012 Roberval Laboratory for Mechanics, Sorbonne Universités, Université de

*Correspondence: fahmi.bedoui@utc.fr; Tel.: +33- 344234528

\section{ABSTRACT}

To understand the effect of mechanical stimulation on cell response, bone marrow stromal cells were cultured on electrospun scaffolds under two distinct mechanical conditions (static and dynamic). Comparison between initial and final cell construct mechanical and biological properties were conducted over 14 days for both culturing conditions. As a result, mechanically stimulated constructs, in contrast to their static counterparts, showed evident mechanical-induced cell orientation, a high amount of aligned collagen along with an abundance of tenomodulin differentiation phenotype. Cell orientation and high collagen production and orientation lead to enhanced storage modulus observed under dynamic stimulation. The increase in tenomodulin under dynamic conditions provided clues on the importance of mechanical stimulation to induce tendon-like phenotype production. Altogether, mechanical stimulation lead to (i) morphological orientation were static cultured constructs presents random morphology, (ii) more pronounced elastic behavior with a limited viscous contribution in the global mechanical response. Such a correlation could help in further studies to use mechanical stimulation as chemical-free cell guidance in tissue engineering development. 
Key words: Electrospinning, Mechanical stimulation, Stem cells, Tissue engineering, tendon

\section{Introduction}

The main objective of tendon tissue engineering is to design and produce a cell-construct that will help to regenerate damaged tissue or mimic it for comprehensive in vitro studies. To achieve this goal, different groups have searched in recent years for the most efficient cells, the right materials, and the appropriate chemical or mechanical environment $(1,2)$. Although the holy grail is still a long way off, most studies have clearly demonstrated the advantages of reproducing the mechanical environment in order to guide the cell-scaffold constructs towards tendon repair(2).

Biomimetic analysis can be considered as essential to guide choices in advanced tissue engineering. Native tendon is made of an anisotropic and viscoelastic material capable of resisting high tensile forces. Tendon cells, mainly tenocytes, are rather scarce, and are responsible for synthesising extracellular matrix, which is mainly composed of type I collagen with a highly organised structure.

As primary tenocytes are rather difficult to collect, bone marrow stromal cells (BMSC) are the most widely used stem cells for tendon tissue engineering, among other stem or progenitor cells, as they have the potential for self-renewal, clonogenicity, and multi-lineage differentiation, including tenogenicity $(3,4)$.

Regarding the scaffold issue, electrospinning has been used for several years to tailor an environment for cell development and differentiation similar to that of extracellular matrix, but with different fibre sizes, porosity, elasticity and mechanical properties for tendon tissue engineering(5). Recently, Lee et al. showed that small, nano-scale random fibres provided a cell environment similar to that found in the inflammatory phase of the tendon healing process, promoting the synthesis of the extracellular matrix (ECM) and cell proliferation, while larger aligned fibres mimicked the normal structure of collagen in tendon, maintaining the tendon cell phenotype(6).

Mechanical stimulation is another key environmental factor for reproducing in vivo conditions. Physiotherapists recommend periodic stretching in training to heal defects or to 
improve capacity(7-10). In vitro, some studies have stated that proper stimuli applied to biohybrid scaffolds could act on cell proliferation, differentiation or function, following mechanotransduction pathways(11-13). While different stimuli have been tested with a wide range of amplitudes, frequencies and time, it should be noted that little is known about how mechanical stress may affect both cell and material responses throughout the tissue engineering process(14). In addition, the parameters assessing the evolution over time of the cell-constructs' mechanical properties are not always relevant. Elastic modulus, stiffness and ultimate tensile strength seem to be accepted as the standard in the field(4). However, native tendon is a viscoelastic material, combining viscous liquid-like, and solidlike behaviour. While the notion of viscoelasticity includes time dependency, meaning that the mechanical response depends on the deformation rate $(\varepsilon)$, tendon tissue engineered constructs tend to be characterised by quasi-static mechanical tests as ranges of strain that do not reproduce physiological conditions. These parameters emphasise on the elastic properties of the material, at a supra-physiological level and with a limited real application. Measured at the beginning and at the end of each experiment, a day-to-day evolution of the mechanical properties of different materials remains utopic.

The objective of this study was to establish a time resolving monitoring approach of the mechanical properties of cell construct under different culturing conditions. Thus, the precise and relevant change in the measured mechanical properties could be used to interpret the cells' responses in close correlation to the chosen biological indicators. Such correlation could help in further studies to use mechanical stimulation as chemical-free cell guidance in tissue engineering development.

In order to better understand this inter-dependency between mechanical stimulations and biohybrid scaffold responses, we performed static and dynamic cultures of rat BMSCs on dedicated random electrospun PCL scaffolds using bioreactors (T6 CellScale and Bose Biodynamic 5100). The mechanical behaviour under a pseudo-physiological strain and cellular activity of the cell-constructs during the stimulation period were recorded and analysed for 12 days, then compared with those obtained under static conditions. At the biological level, we focused on cell proliferation, differentiation towards tendon lineage (in the absence of specific differentiation factors) and organisation of the neo-synthetized ECM. 
At the mechanical level, we followed up the changes in both the viscous and elastic properties of the pure and cell-seeded scaffolds. Therefore, we propose to evaluate different mechanical markers of both elasticity and viscoelasticity such as energy dissipation, damping factor ( $\tan \delta)$, storage modulus ( $\left.E^{\prime}\right)$ and loss modulus ( $\left.E^{\prime \prime}\right)$, already used in the mechanobiology field to analyse the performance of native tendons.

\section{Materials and Methods}

\section{- Electrospun scaffold preparation and characterisation}

Poly( $\varepsilon$-caprolactone) (PCL, MW=80kg. $\mathrm{mol}^{-1}$ Sigma Aldrich, United States) was dissolved in dichloromethane (DCM, Sigma-Aldrich)/N,N-dimethylformamide (DMF, ReagentPlus ${ }^{\circledR}$ SigmaAldrich, USA) $(80 / 20 \mathrm{v} / \mathrm{v})$ for $24 \mathrm{~h}$ to make an electrospinning solution at $10 \mathrm{wt} \%$. Once dissolved, the solution was poured into a $10 \mathrm{ml}$ glass syringe. Scaffold fabrication was performed over a rotating collector for $3 \mathrm{H}$ (distance $15 \mathrm{~cm}$, flow rate $0.017 \mathrm{ml} / \mathrm{min}$, needle diameter 18G, voltage $15 \mathrm{kV})$. In order to evaluate the morphology and mechanical properties of the PCL scaffolds, scanning electron microscopy and tensile testing were carried out retrospectively.

The morphology of the electrospun scaffolds was observed using scanning electron microscopy (Philips XL30 ESEM-FEG). Electrospun mats were cleaned with ethanol and goldcoated prior to observation. To analyse the diameter of the electrospun 10 wt \% PCL fibres, ImageJ software was used. After setting up the scale, a line was drawn manually across the diameter of randomly-selected fibres $(n=50)$ from 3 different SEM micrographs. The degree of isotropy in two samples from three scaffolds $(n=6)$ was analysed using Mountain ${ }^{\text {TM }}$ software. The main directions of the fibres were analysed using the Fourier Transform method.

The scaffold modulus for dry and wet scaffolds was quantified using uniaxial tensile testing. Three samples for each scaffold $(n=3)$ were shaped into a strip measuring $1.0 \mathrm{~cm} \times 3.0 \mathrm{~cm}$. For wet samples, the scaffolds were immersed in ethanol 70\% (Sigma-Aldrich, USA) for 45 min then washed three times with PBS 7.4 (phosphate buffered saline, Gibco Invitrogen, USA). The thickness was evaluated using a precision dial thickness gauge (Mitutoyo Corporation, Japan). The samples were secured within the metallic grips of the tensile tester 
118 (Bose Electroforce 3200, TA, USA) and elongation at $0.1 \mathrm{~mm} \mathrm{~s}^{-1}$ was performed with a 119 working load of $22 \mathrm{~N}$. The applied force was measured each second and the modulus 120 obtained from the slope of the linear region.

- Cell harvesting and culture

Bone marrow stromal cells (BMSCs) were isolated from rat bone marrow thanks to their short-time adherence to plastic, in accordance with previously described protocols(15). Briefly, 6-week-old male Sprague Dawley rats $(n=4)$ were sacrificed, and both right and left femurs were aseptically removed and washed 3 times with 1x PBS 7.4 (phosphate buffered saline, Gibco Invitrogen, USA). Next, bone marrow was flushed out using $\alpha$-MEM culture medium (PAN BIOTECH, Germany) supplemented with 10\% foetal bovine serum (FBS, Gibco Invitrogen, USA), 1\% penicillin-streptomycin (Gibco Invitrogen, USA) and 1\% amphotericin B (PAN BIOTECH, Germany). The released cells were then collected into 6-well dishes (BD Falcon $^{\mathrm{TM}}$, USA). After $24 \mathrm{~h}$, non-adherent cells were carefully discarded and adherent cells were cultured with fresh $\alpha$-MEM for 6-7 days, the time needed for BMSC colonies to reach confluence. The cell culture media were replaced every 3 days. When the culture dishes started to approach confluence, the cells were detached and serially subcultured. The cells at the third passage (P3) were used for the cell seeding experiments. Experimental procedures involving animals were carried out on euthanised animals within the approved structure (E60 159 01). Both the procedures and the treatment of the animals complied with the principles and guidelines of the French legislation on animal welfare (No. 2013-118) and the Directive if the European Communities (2010/63/EU).

Electrospun mats were cut into strips measuring $40 \times 12.5 \mathrm{~mm}$ or $35 \times 9 \mathrm{~mm}$ as shown in Supplementary Table ST2, disinfected with ethanol 70\% (Sigma-Aldrich, USA) for 45 min, and then washed three times with PBS for $10 \mathrm{~min}$. Disinfected scaffolds were soaked in fresh $\alpha$-MEM for $48 \mathrm{~h}$ before seeding the cells. After that, the media was discarded and each scaffold was plated with a density of $6 \times 10^{4}$ cells $\mathrm{cm}^{-2}$.

145 After two days of static culture, each construct was placed in a bioreactor for mechanical stimulation or in well dishes for static culture. Mechanically-stimulated cell constructs were stretched twice a day at $5 \%$ strain for $1 \mathrm{~h}$ at $1 \mathrm{~Hz}$ with $11 \mathrm{~h}$ of rest between each cycle for 5 or 
12 days (considered as 1 or 2 weeks of culture time respectively). For this purpose, two different bioreactors were used: (1) the MechanoCulture T6 Mechanical Stimulation System (CellScale Biomaterials Testing, Waterloo, ON, Canada), consisting of an actuator and screwdriven clamp grips mounted inside a cell culture chamber capable of applying uniaxial stretching to 6 parallel samples, was chosen for the biological assays. Cell culture media were replaced every 5 days, and (2) the Bose Biodynamic 5100 (TA Electroforce ${ }^{\circledR}$, USA), consisting of a cell culture chamber connected to a flow pump in which one sample was attached thanks to a system of rods and clamps. One rod was attached to a step motor making it possible to apply uniaxial displacement. The other rod was connected to a force transducer of $22 \mathrm{~N}$ making it possible to constantly monitor the force applied to each displacement. Cell culture media circulated continuously through the flow pump connected to a reservoir of $500 \mathrm{~mL}$, making it possible to maintain the culture for up to two weeks. This system was chosen for biomechanical evaluation. For static culture, each construct was cultured for 5 or 12 days without tension and the cell culture media were replaced every 3 days.

\section{Biological and mechanical evaluation of cell-constructs}

To investigate the effects of dynamic culture on cell activity, seeded PCL 10 -wt \% scaffolds were secured in the grips of the T6 CellScale bioreactor after two days of static culture and cultured for 5 or 12 days under dynamic culture conditions ( $5 \%$ strain for $1 \mathrm{~h}$ at $1 \mathrm{~Hz}$ with $11 \mathrm{~h}$ of rest). After this time, the cell-constructs were removed for biological analyses.

Total deoxyribonucleic acid (DNA) and collagen from each sample were extracted at 5 or 12 days of static or dynamic culture with the reagent, Trizol (TRI Reagent ${ }^{\circledR}$, Sigma-Aldrich, USA) according to the manufacturer's protocol. Briefly, once lysed by the action of $1 \mathrm{ml}$ of Trizol, chloroform (Sigma-Aldrich, USA) was added to obtain a colourless upper aqueous phase with RNA, an interphase with DNA, and a lower red phenol-chloroform phase with proteins. DNA was then isolated and quantified using NanoDrop ND-1000 (Thermo Scientific, USA). Proteins were isolated and hydrolysed in $6 \mathrm{~N} \mathrm{HCl}$ (Sigma-Aldrich, USA), and total hydroxyproline content was determined using hydroxyproline assay (Hydroxyproline Assay Kit, Sigma-Aldrich, USA)(16). Hydroxyproline content was related to the collagen content(17). 
178 After 5 or 12 days of static or dynamic culture, cells-constructs were fixed in a solution of $4 \%$ $179(\mathrm{w} / \mathrm{v})$ paraformaldehyde solution (PAF, Agar Scientific, United Kingdom) in PBS for 15 min 180 then rinsed three times with PBS 7.4. After 10 min of permeabilization in a solution of PBS181 Triton X-100 0.5\% (v/v) (VWR, United Kingdom), cell-constructs were blocked at 4으 182 overnight with a solution of $1 \%(\mathrm{w} / \mathrm{v})$ BSA (Sigma-Aldrich, USA). The morphology of the 183 rBMSCs under static or dynamic culture was assessed using rhodamine phalloidin 184 (Invitrogen, USA) to selectively stain the F-actin. For immunofluorescence staining, cellconstructs were treated with mouse primary antibodies anti-rat collagen type I (COL1, 1:100, Abcam, United Kingdom) or to anti-rat tenomodulin (TNMD, 1:200, Abcam, United Kingdom) overnight at $4^{\circ} \mathrm{C}$. After incubating overnight at $4^{\circ} \mathrm{C}$ with secondary fluorescent antibodies donkey anti-mouse 488 (Invitrogen, USA). Hoechst 33342 (Sigma-Aldrich, USA) was added as counterstaining for cell nuclei. Z-stacks were then acquired on an Inverted ZEISS 710 confocal microscope (Zeiss, Germany).

191 To investigate the effects of dynamic culture on the evolution of the mechanical properties of the cell-constructs, seeded scaffolds or scaffolds without cells were mounted in the Bose Biodynamic 5100 for 12 days under mechanical stimulation. Bose Biodynamic 5100 consists of one culture chamber with two rods, one connected to a motor and the other to a force transducer of $22 \mathrm{~N}$. The entire system is placed in an incubator making it possible to control the temperature and $\mathrm{CO}_{2}$ at $37{ }^{\circ} \mathrm{C}$ and $5 \%$ respectively. Cell culture media circulated continuously thanks to a system of peristaltic pumps connected to the cell chamber. The bioreactor makes it possible to apply defined cyclic (sinusoidal) strain to the cell-seeded or empty scaffolds, and to concomitantly record the resulting stress. Either stress ( $\sigma$ ) or strain ( E) could be set up as the driving parameter. We decided to set deformation, $5 \%$ cyclic sinusoidal strain as the control parameter. We recorded the resulting force at 20 points per second, corresponding to 20 points per sinus, during the 12 days of dynamic culture.

$$
\text { Stress } \sigma=\sigma_{0} \sin (w t-\delta)(2)
$$

205 Where $\varepsilon_{0}$ and $\sigma_{0}$ are the initial strain and stress respectively, and $\omega$ and $\delta$ are the frequency 206 and dephasing angle between stress and strain respectively. Plotting together stress vs 207 strain, we were able to calculate the relative dissipation energy by calculating the surface 
between the curves in each sinus. Because sinusoidal stress was applied, we also determined the storage modulus $\left(E^{\prime}\right)$, loss modulus $\left(E^{\prime \prime}\right)$, complex modulus $\left(E^{*}\right)$ and $\tan \delta$. All equations are indicated below:

$$
\begin{aligned}
& E^{\prime}=\frac{\sigma_{0}}{\varepsilon_{0}} \cos (\delta)(3) \\
& E^{\prime \prime}=\frac{\sigma_{0}}{\varepsilon_{0}} \sin (\delta)(4) \\
& E^{*}=\sqrt{E^{\prime 2}+E^{\prime 2}}(5) \\
& \tan (\delta)=\frac{E^{\prime \prime}}{E^{\prime}}(6)
\end{aligned}
$$

For analysis, each $1 \mathrm{~h}$ cycle, consisting of 3600 sinuses, was divided into six intervals of 600 sinus and the results are given as an arithmetic average. After the first analysis, we decided to represent the results from 1200 to 3600 sinus of each cycle, where a closed loop region was found. For statically-cultured cell-constructs and controls, each sample was placed on the bioreactor and, once secured between the rods, one cycle of 3600 sinus was set at a given time ( 7 and 14 days) to compare in the same way as the dynamic conditions. For the control without cells, scaffolds were subjected to the same parameters as the cellconstructs, including disinfestations and incubation with cell culture media.

\section{Statistical analysis}

At least 6 independent experiments, except for the biomechanical analysis $(n=3)$ carried out on the Bose Biodynamic 5100, were performed. Each result (mechanical properties as damping factor, loss and storage modulus) represents an arithmetic average the different analyzed tests. Data are therefore presented as an average along with the appropriate mean standard deviation. The significance of the results was tested by analysing the variance (ANOVA) with Turkey's post hoc test in the case of multiple comparisons.

On behalf of the authors, we declare, that all the methods were carried out in accordance with relevant guidelines and regulations. In addition all experimental protocols were approved by our institution (Sorbonne Université Alliance, Université de Technologie de Compiègne) commitees. 
Results

\section{- PCL scaffold synthesis and characterisation}

236

Scaffolds were prepared using electrospinning laboratory made setup (Fig 1). The prepared 237 scaffolds were meant to be used for cell culture under different conditions; static and dynamic culturing as presented schematically in figure 2 (Fig 2). Electrospinning PCL into a DCM/DMF 4:1 co-solvent led to the production of a homogenous scaffold without pearls. SEM images showed a final material composed of a dense network of continuous smooth fibres (Fig 3A), as found in (18). These fibres presented an average diameter of $0.52 \pm 0.25$ $\mu \mathrm{m}$. Distribution analyses of the fibres revealed a random conformation (Fig 3B). The scaffolds were then characterised following the uniaxial traction test described in the Materials and Methods section. In order to evaluate potential alteration of the mats in an aqueous solution, the scaffolds were analysed in both dry and wet conditions. Stress/strain profiles were similar, showing a "J" zone, characteristic of the nonlinear mechanical response of material, in which we were able to identify three different regions; the toe region ( $<2 \%$ strain), heel region ( $<8 \%$ strain) and linear region ( $<18 \%$ strain) (Fig 4 A). Both elastic moduli were similar, with $8.05 \pm 0.82 \mathrm{MPa}$ for the dry scaffolds and $7.93 \pm 2.66 \mathrm{MPa}$ for the wet ones (Fig 4B).

251

\section{- Biological outcomes and tendon extracellular matrix deposition}

The number of cells presented on the constructs was assessed by means of DNA quantification. The amount of DNA was observed in either static or dynamic conditions after 2 weeks (Fig 5\#). Dynamic stimulated cell-constructs appeared to have greater number of cells compared to static cultures with $4.1 \pm 1.3 \times 10^{6}$ vs $2.91 \pm 0.8 \times 10^{6}$ respectively, after 2 weeks of culture, although the difference was not statistically significant.

In order to determine the effect of the mechanical stretching on ECM neo-synthesis, hydroxyproline was measured (Fig 5§). Hydroxyproline concentration is related to fibrillar collagen and comprises around $13.5 \%$ of the collagen(19). It could be detected in all the culture conditions. After a week of culture, no difference in collagen production was observed between the static or dynamic conditions. After two weeks, a significant increase in collagen synthesis under dynamic stretching was noted, with $18.8 \pm 2.6 \mu \mathrm{g}$ vs $12.1 \pm 1.4$ 
$264 \mu \mathrm{g}$ of hydroxyproline for the static culture. Mechanical stimulation thus induced elevated collagen content in the scaffold, compared to the static culture.

To better understand cell organisation, fluorostaining of the actin cytoskeleton was performed (Fig $5^{*}$ ). Cells cultured in the absence of mechanical stimulation presented a random morphology on the scaffold. This behaviour did not evolve with culture time, with the same observations at 1 or 2 weeks (Fig 5* A-D). On the contrary, when submitted to mechanical stimulation, cells presented an elongated shape and appeared aligned with the stretching direction. This effect seemed more pronounced after two weeks of stimulation, with thinner elongated cells at the surface of the material (Fig 5* D).

To determine the possible differentiation of BMSCs towards tendon lineage under both static and dynamic culture conditions, immunofluorescence staining of type 1 collagen, the main constituent of tendon ECM, and tenomodulin, a tendon specific marker, was performed at different time points. Type-1 collagen was found in both conditions at 1 or 2 weeks of culture (Fig 5* E-H). After 1 week of culture, type-1 collagen structures were aligned with the stretching under dynamic conditions (Fig $5^{*}$ F), while in static culture they were present in a random manner (Fig 5* E). After 2 weeks of culture, the same trend was confirmed. Collagen fibres seemed to be more abundant compared with the first week of culture (Fig 5* G, H). While there were some clusters of aligned collagen on the static culture (Fig 5* G), under the effect of mechanical stimulation, the collagen was highly organised, with collagen fibres aligned towards the stretching axis.

Immunofluorescence staining revealed the presence of tenomodulin on both culture conditions. In the same manner as collagen fibres, an alignment was observed when the cell-constructs where mechanically stretched (Fig 5* I-L). After one week of culture, tenomodulin appeared to be clearly aligned under dynamic conditions (Fig $5^{*} \mathrm{~J}$ ) compared to the static culture (Fig $5^{*}$ I). This effect was more difficult to visualise after two weeks due to the total distribution of tenomodulin and the high cell density (Fig $5^{*} \mathbf{K}, \mathbf{L}$ ).

\section{- Mechanical stimulation and biomechanical evaluation of cell construct}

Initially, static tests were conducted on dry and wet scaffolds. Those tests help deriving elastic modulus (E) by plotting the slope of the stress vs strain curve, corresponding to the linear zone of our material as shown in figure 4 (Figure 4), due to the non-linearity at the 
295

296

297

298

299

300

301

302

303

304

305

306

307

308

309

310

311

312

313

314

315

316

317

318

319

320

321

322

323

initial part of the curve. Dynamic testing were, however conducted at $5 \%$ dynamic strain, which means that the dynamic strain was imposed within the non-linear regime of the stress-strain curve.

After 2 days of static culture, the cell-construct or the control scaffolds were fixed inside the bioreactor chamber and the mechanical test was launched. Both signal force and displacement were recorded over time and found to be smooth, without any background noise, making it possible to monitor mechanical (elastic and viscoelastic) properties (Fig 6A).

The relative dissipation energy or hysteresis can be calculated by calculating the surface area between the curves, along with the damping factor (Fig 6A). All the relevant parameters were extracted following the equations described previously and presented in

Fig 7, to follow the tissue response continuously instantaneously and after two weeks of culture.

Initially (i.e. on day 2), in terms of viscous ( $\tan \delta$, dissipated energy and $E^{\prime \prime}$ ) and elastic ( $\left.E^{\prime}\right)$ properties, along with the complex modulus $\left(E^{*}\right)$, no significant differences were found between the different parameters for the different culture conditions with or without cells, however, slight trends can be drawn between the different conditions. For $\tan \delta$, similar values were found for each condition in both cell constructs and controls with $0.08 \pm 0.01$ vs $0.12 \pm 0.03$ in static conditions and $0.09 \pm 0.01$ vs $0.09 \pm 0.03$ in dynamic ones. For the dissipated energy (hysteresis), cell-constructs seemed to present lower values than controls, with $0.64 \pm 0.35$ vs $0.92 \pm 0.14$ in static conditions and $0.90 \pm 0.11$ vs $1.47 \pm 0.57$ in dynamic ones (Fig 7). For E", another parameter related to viscosity, the same trend was found, with lower values for cell-constructs $(0.30 \pm 0.16 \mathrm{MPa} \& 0.37 \pm 0.13 \mathrm{MPa})$ in both static and dynamic conditions, compared to controls $(0.42 \pm 0.07 \mathrm{MPa} \& 0.59 \pm 0.14 \mathrm{MPa})$. In terms of elastic properties, the storage modulus $\left(E^{\prime}\right)$ appeared higher for the dynamic control with $6.63 \pm 0.89 \mathrm{MPa}$. $E^{*}$ followed the same trends as $E^{\prime}$, with the highest value found for dynamic control (6.68 $\pm 0.87 \mathrm{MPa})$.

After 14 days of culture, the results showed a slight increase in tan $\delta$, dissipated energy and E" for cell-constructs, both static and dynamically cultured (Fig 7), compared to both static and dynamic controls. For $E^{\prime}$ and $E^{*}$, the same trend was found after 14 days of culture, with 
324

values for statically cultured cell-constructs of $4.24 \pm 0.78 \mathrm{MPa}$ and $0.44 \pm 0.08 \mathrm{MPa}$ respectively and $5.04 \pm 0.11 \mathrm{MPa}$ and $0.49 \pm 0.02 \mathrm{MPa}$ for cell-constructs under dynamic stimulation.

To better determine the effects of mechanical stimulation and cell culture on different groups, we decided to analyse the variation $(\mathrm{V} \%)$ in the mechanical parameters $(\mathrm{P})$ between the first cycle of day 2 (i.e. the first day of mechanical stimulation) and the last cycle of day 14 (i.e. the last day of culture) (Fig 8).V\% $=100 *\left(P_{d 14}-P_{d 2}\right) / P_{d 2}$.

Although not statistically significant, some trends are present in each of the mechanical properties analysed. In the absence of cells, all mechanical parameters presented lower percentages than those obtained in cell-constructs (Figure 8). Tan $(\delta)$ presented a slight increase for static controls $(4 \pm 7 \%)$ and decreased for dynamic ones $(-3 \pm 6 \%)$. For dissipated energy, controls presented a decrease of $-4 \pm 17 \%$ and $-10 \pm 2 \%$ for static and dynamic conditions respectively. E" presented the same trend as dissipated energy, with the highest decrease obtained for static conditions $(-25 \pm 4)$ compared to dynamic ones $(-9 \pm$ $6 \%)$. The elastic parameter $\left(E^{\prime}\right)$ appeared to decrease particularly for the static control $(-20 \pm$ $9 \%)$, compared to a slight reduction for the dynamic control $(-6 \pm 0.1 \%)$. E* followed the same trends as $E^{\prime}$, with the highest decrease found with the static control with $-20 \pm 9 \%$ vs $6 \pm 0.2 \%$ for the dynamic control.

In the presence of cells, Tan $\delta$ seemed to increase in both static and dynamic cultures, with an enhancement of $22 \pm 16 \%$ and $16 \pm 5 \%$ respectively. Dissipated energy presented a similar trend with enhancement of $25 \pm 7 \%$ and $14 \pm 9 \%$ for static and dynamic culture of cell-constructs, respectively. In terms of $E^{\prime \prime}$, cell-constructs presented an increase of $45 \pm 5 \%$ for static and $31 \pm 19 \%$ for dynamically-cultured cell-constructs. For $E^{\prime}$, dynamically-cultured cell-constructs presented the highest increase, with $16 \pm 20 \%$, while for static cultures a slight increase of $7 \pm 6 \%$ was found. Regarding $E^{*}$, the same trends appeared as for $E^{\prime}$, with the highest increase for dynamic conditions (16 $\pm 20 \%)$.

Static control appeared to have the lowest values for $E^{\prime}, E^{\prime \prime}$ and $E^{*}$, followed by dynamic control. On the other hand, both cell-constructs (dynamic or static cultured) presented the 
352

353

354

355

356

357

358

359

360

361

362

363

364

365

366

367

368

369

370

371

372

373

374

375

376

377

378

379

highest enhancement of mechanical properties over time, with higher viscosity for static conditions and higher elasticity for dynamic ones

\section{Discussion}

Our scientific goal was to understand any correlation between the changes on the mechanical properties of the biohybrid scaffold and the activity of the seeded BMSCs, in association with the production and arrangement of the newly-formed ECM produced by cells. To the best of our knowledge, this analysis, which requested an adequate cell culture protocol, has not yet been investigated. Therefore, we first needed to confirm the role of mechanical stimulation on BMSC differentiation towards tendon lineage when cultured on adapted scaffolds.

In this study, we proposed to follow the cell-constructs' mechanical properties with a set of relevant parameters $\left(E^{\prime}, E^{\prime \prime}\right.$ and $\left.\tan \delta\right)$ throughout the entire dynamic stimulation and key parameters of cell activity as proliferation, orientation differentiation. Our experiment, generating $5 \%$ of strain at $1 \mathrm{~Hz}$, represents a dynamic testing involving continuous repeated sine strain simulating physiological activities for tendons(20).

Our first concern was thus to develop a biomaterial suitable for this approach. Electrospinning has been widely used in the development of materials mimicking the fibrous nature of the tendon extracellular matrix(21). While our PCL scaffold presented an elastic modulus of $8.05 \pm 0.82 \mathrm{MPa}$ (Fig 3), which is still a long way from native tendon(22), the stress-strain curve revealed three regions similar to those found in tendons(4). Taking into account this stress-strain response, and comparing them with the mechanical behaviour of tendon, we decided to apply a cyclic sinusoidal strain of $5 \%(0-5 \%)$ corresponding to the heel region of both tendon and our electrospun scaffold. This was intended to calculate the viscoelastic behaviour of our cell-constructs when submitted to cyclic stretching with repeated stretching cycles and strain rates within a low range. The effect of this mechanical protocol was analysed for cell behaviour, mechanical changes over time and the correlation between both variables.

(1) Cell behaviour over mechanical stimulation 
380

381

382

383

384

385

386

387

388

389

390

391

392

393

394

395

396

397

398

399

400

401

402

403

404

405

406

407

408

409

Regarding the cell behaviour, after one week of culture, there was no difference in terms of proliferation between static and dynamic conditions (Fig 5\#). After two weeks, the number of cells was found to have tripled for the static culture and even quadrupled for cells submitted to dynamic stretching. We can thus conclude that the mechanical stimulation enhanced the proliferative ability of BMSCs, inducing an increase in cell proliferation in response to mechanical load. This result is consistent with other experiments conducted with BMSCs, where more cells were found after 2 weeks of culture compared to shorter culture times under $5 \%$ of stretching(23). Other studies have shown similar results with fibroblasts(24) and TDSCs(25). While an increase in cell proliferation is found as a response to mechanical stimulation, the mechanisms involved in this mechano-response still need to be clarified(26).

When stimulated, BMSCs presented an elongated morphology aligned with the stretching direction (Fig 5* B,D), while cells cultured under static conditions were randomly organised on the scaffold (Fig $\mathbf{5}^{*} \mathbf{A}, \mathbf{C}$ ). Similar behaviour was found in another study that analysed the impact of mechanical stimulation on cell alignment when cultured on randomly-oriented scaffolds in the same range of nanofiber size(27).

Regarding collagen synthesis, the cell-constructs showed continuous production over time, with more collagen found after 2 weeks of culture for each condition (Fig 5§). After two weeks of culture, more collagen was found on cell-constructs subjected to mechanical stretching, in agreement with several other studies(28-30). This effect has been shown consistently in in vivo studies carried out on tendons where an increase in collagen synthesis was observed as a part of the tendon adaptation response to continuous mechanical loading(31).

Analysis of the ECM produced by cells in both static and dynamic cultures was also performed by immunofluorescence staining of type I collagen and tenomodulin (Fig $5^{*}$ ). Collagen $\mathrm{I}$ is the most abundant collagen in tendons, and tenomodulin is a late tendon differentiation marker, and a key glycoprotein for the mature state of tendons $(32,33)$. Both were more abundant under mechanical stimulation when compared to static culture samples. Furthermore, they appeared to be arranged in the stretching direction. Taken together, these data with cell alignment achieved in dynamic conditions, revealed a tendon- 
410 like phenotype of BMSCs under dynamic culture conditions, similar to native tendon 411 arrangement(34).

412 (2) Mechanical stimulation; impact of the culturing conditions.

413 Concerning the evolution of the biomechanical behaviour and to avoid the noise, we 414 decided to analyse and represent the $\mathrm{V} \%$ of the targeted parameters variations as 415 described before with the equations, from the 1200 to 3600 sinus where a neat loop was 416 observed, similar to the mechanical behaviour observed in tendons(35). For both static and 417 dynamic controls, $E^{\prime}, E^{\prime \prime}$ and Tan $\delta$ seem to present a reduction while for cell constructs 418 those parameters seem to increase over time (Fig 8), which maybe result of cellular 419 behaviour.

420 The elastic modulus $\mathrm{E}^{\prime}$ considers the elastic properties both from the material and for cells. 421 The increase over time could be explained as the result of newly deposited type I collagen 422 fibres. Type I collagen is effectively an important stress-bearing component of connective 423 tissues. It is secreted by cells and hierarchically assembled into fibrils from a packaging of 424 collagen molecules, embedded in a soft matter formed of water and proteoglycans. This 425 organisation gives the collagen structure enough rigidity to be considered an elastic 426 beam(36). In addition, the aligned orientation adopted by collagen fibres (Fig $5^{*}$ ) through 427 the stretching direction could explain the higher $E^{\prime}$ percentage (16\%) for dynamically428 cultured cell-constructs compared to static culture (7\%), as aligned collagen fibres are better 429 suited up to supporting tensile stress(37).

430 The loss modulus ( $\left.E^{\prime \prime}\right)$ takes into account the viscous behaviour, therefore its energy 431 dissipation behaviour and confirmed our previous results. As seen before, when initial and 432 last values were compared (Fig 8), the controls without cells presented a reduction in E" 433 with $-25 \%$ for static and $-9 \%$ for dynamic controls.

434 The cell-constructs showed an increase of E" for both static and dynamic conditions. 435 However, this increase seemed to be higher for static conditions with $45 \%$ increase, 436 compared with $31 \%$ for dynamic cultures. Taken together, these results consistently 437 demonstrated that cell-constructs, presented increased viscosity over time, compared to 438 nude biomaterials. Finally, dynamic cultures exhibited a greater increase in the elastic 439 properties of the cell-constructs, with a lesser gain in viscous properties, while the static 
440 cultures had a greater influence on the viscous properties, with a lower increase in 441 elasticity.

442 This effect may be explained by the effect of the alignment of the extracellular matrix, 443 particularly the collagen fibres, which align through the tensile axis, resulting in an increase 444 in the elastic properties of the cell-constructs exposed to dynamic culture conditions (Fig $\left.445 \quad 5^{*}\right)$.

446 Others viscous related parameters as $\tan \delta$ seem to be in accordance with these results. The value of $\tan \delta$ is an indicator of how efficiently the material absorbs and dissipates energy 448 due to fiber-cells rearrangements and internal friction. When we compared its evolution 449 over time (Fig 8), both controls presented the lowest values.

450 Cell-constructs, in both static and dynamic cultures, presented an enhanced tan $\delta$ of $22 \%$ 451 and $16 \%$ respectively, compared to cell-free control scaffolds (Fig 8). Because $\tan \delta$ 452 represents the ratio of Loss over storage modulus, the highest values of $\tan \delta$ were related to a higher damping factor. In a rabbit Achilles tendon regeneration model, Nagasawa et al. 454 found higher values of $\tan \delta$ for regenerated tendons after surgery compared to controls(33). This increase was explained as the result of the neosynthesis of collagen fibres. As this "new" fibre presented a lower amount of mature cross-linking, collagen mobility was increased within the tissue, resulting in more energy dissipation. This may explain the increase in tan $\delta$ in our cell-constructs, where cells produced collagen, compared to controls without cells. In addition, the random organisation of collagen fibres for static conditions may explain the greater $\tan \delta$ percentages. These results are in accordance with others mechanical parameters studied here (Supplementary data) as energy dissipation and $\mathrm{E}^{*}$. Correlating both the biological and mechanical results (Fig 9), it seems that mechanical stimulation has a positive effect on cell proliferation and collagen synthesis, which was greater than static culture conditions. Cell and collagen alignment, together with an increase in tenomodulin under dynamic culture conditions, provides a better environment for BMSCs to differentiate towards a tendon-like phenotype. Furthermore, the mechanical properties of the cell-constructs were enhanced over time compared to the control scaffolds without cells. This could be explained as a result of the cellular activity, translated into the production of an ECM. By synthesising collagen, which in tendons and ligaments is responsible for its mechanical properties, the viscous properties (tan delta, dissipated 
471 energy and $\left.E^{\prime \prime}\right)$ were increased in both the static and dynamic cultures. The random nature 472 of this ECM conferred higher viscous properties for cells cultured under static conditions, 473 explained as an increase in the mobility of collagen and the associated water molecules 474 within these random fibres, while dynamically-stimulated cell-constructs presented aligned 475 collagen fibres towards the direction of the stretching. These aligned fibres could better 476 retain water molecules, resulting in less mobility compared to random ones. In addition, due 477 to the elastic nature of the collagen fibres when they are stretched, the alignment may 478 explain a greater increase in elasticity ( $\left.E^{\prime}\right)$ under mechanical cultivation.

\section{Acknowledgment}

480 This work was carried out and funded in the framework of the Labex MS2T. It was 481 supported by the French Government, through the program "Investments for the future" managed by the National Agency for Research (reference ANR-11-IDEX- 0004-02) and by 483 Reǵion Hauts de France (INTIM project).

\section{Data availability}

The data supporting the findings of this study are available from the authors upon reasonable request.

\section{References}

1. Shearn JT, Kinneberg KRC, Dyment NA, Galloway MT, Kenter K, Wylie C, et al. Tendon Tissue Engineering: Progress, Challenges, and Translation to the Clinic. J Musculoskelet Neuronal Interact. 2011 Jun;11(2):163-73.

2. Butler DL, Juncosa-Melvin N, Boivin GP, Galloway MT, Shearn JT, Gooch C, et al. Functional tissue engineering for tendon repair: A multidisciplinary strategy using mesenchymal stem cells, bioscaffolds, and mechanical stimulation. J Orthop Res Off Publ Orthop Res Soc. 2008 Jan;26(1):1-9.

3. Yin Z, Chen X, Chen JL, Shen WL, Hieu Nguyen TM, Gao L, et al. The regulation of tendon stem cell differentiation by the alignment of nanofibers. Biomaterials. 2010 Mar;31(8):2163-75.

4. Beldjilali-Labro M, Garcia Garcia A, Farhat F, Bedoui F, Grosset J-F, Dufresne M, et al. 
501

502

503

504

505

506

507

508

509

510

511

512

513

514

515

516

517

518

519

520

521

522

523

524

525

526

527

528

529

530

531

532

533

534

5. Kishan AP, Cosgriff-Hernandez EM. Recent advancements in electrospinning design for tissue engineering applications: A review. J Biomed Mater Res A. 2017 Oct;105(10):2892-905.

6. Lee NM, Erisken C, Iskratsch T, Sheetz M, Levine WN, Lu HH. Polymer fiber-based models of connective tissue repair and healing. Biomaterials. 2017;112:303-12.

7. Maffulli N, Longo UG, Loppini M, Spiezia F, Denaro V. New options in the management of tendinopathy. Open Access J Sports Med. 2010 Mar 31;1:29-37.

8. Magnusson SP, Langberg $\mathrm{H}$, Kjaer $\mathrm{M}$. The pathogenesis of tendinopathy: balancing the response to loading. Nat Rev Rheumatol. 2010;6(5):262-8.

9. Andersson T, Eliasson P, Hammerman M, Sandberg O, Aspenberg P. Low-level mechanical stimulation is sufficient to improve tendon healing in rats. J Appl Physiol Bethesda Md 1985. 2012 Nov;113(9):1398-402.

10. Eliasson P, Andersson T, Aspenberg P. Influence of a single loading episode on gene expression in healing rat Achilles tendons. J Appl Physiol Bethesda Md 1985. 2012 Jan;112(2):279-88.

11. Humphrey JD, Dufresne ER, Schwartz MA. Mechanotransduction and extracellular matrix homeostasis. Nat Rev Mol Cell Biol. 2014 Dec;15(12):802-12.

12. Lee J, Guarino V, Gloria A, Ambrosio L, Tae G, Kim YH, et al. Regeneration of Achilles' tendon: the role of dynamic stimulation for enhanced cell proliferation and mechanical properties. J Biomater Sci Polym Ed. 2010;21(8-9):1173-90.

13. Engebretson B, Mussett ZR, Sikavitsas VI. Tenocytic extract and mechanical stimulation in a tissue-engineered tendon construct increases cellular proliferation and ECM deposition. Biotechnol J. 2017 Mar;12(3).

14. Engebretson B, Mussett ZR, Sikavitsas VI. The effects of varying frequency and duration of mechanical stimulation on a tissue-engineered tendon construct. Connect Tissue Res. 2018;59(2):167-77.

15. Li X, Zhang Y, Qi G. Evaluation of isolation methods and culture conditions for rat bone marrow mesenchymal stem cells. Cytotechnology. 2013 May;65(3):323-34.

16. Neidert MR, Lee ES, Oegema TR, Tranquillo RT. Enhanced fibrin remodeling in vitro with TGF-beta1, insulin and plasmin for improved tissue-equivalents. Biomaterials. 2002 Sep;23(17):3717-31.

17. Marturano JE, Arena JD, Schiller ZA, Georgakoudi I, Kuo CK. Characterization of mechanical and biochemical properties of developing embryonic tendon. Proc Natl Acad Sci. 2013 Apr 16;110(16):6370-5. 
18. Gholipour Kanani A, Bahrami SH. Effect of Changing Solvents on Poly( $\boldsymbol{\varepsilon}$-Caprolactone) Nanofibrous Webs Morphology [Internet]. Journal of Nanomaterials. 2011 [cited 2020 Feb 12]. Available from: https://www.hindawi.com/journals/jnm/2011/724153/

19. Stoilov I, Starcher BC, Mecham RP, Broekelmann TJ. Chapter 7 - Measurement of elastin, collagen, and total protein levels in tissues. In: Mecham RP, editor. Methods in Cell Biology [Internet]. Academic Press; 2018 [cited 2020 Feb 12]. p. 133-46. (Methods in Extracellular Matrix Biology; vol. 143). Available from: http://www.sciencedirect.com/science/article/pii/S0091679X17301292

20. Ikoma K, Kido M, Nagae M, Ikeda T, Shirai T, Ueshima K, et al. Effects of stress-shielding on the dynamic viscoelasticity and ordering of the collagen fibers in rabbit Achilles tendon. J Orthop Res Off Publ Orthop Res Soc. 2013 Nov;31(11):1708-12.

21. Bölgen N. 10 - Electrospun materials for bone and tendon/ligament tissue engineering. In: Uyar T, Kny E, editors. Electrospun Materials for Tissue Engineering and Biomedical Applications [Internet]. Woodhead Publishing; 2017 [cited 2020 Feb 12]. p. 233-60. Available from: http://www.sciencedirect.com/science/article/pii/B9780081010228000041

22. Martin RB, Burr DB, Sharkey NA, Fyhrie DP. Mechanical Properties of Ligament and Tendon. In: Martin RB, Burr DB, Sharkey NA, Fyhrie DP, editors. Skeletal Tissue Mechanics [Internet]. New York, NY: Springer; 2015 [cited 2020 Feb 12]. p. 175-225. Available from: https://doi.org/10.1007/978-1-4939-3002-9_4

23. Choi K-M, Seo Y-K, Yoon H-H, Song K-Y, Kwon S-Y, Lee H-S, et al. Effects of mechanical stimulation on the proliferation of bone marrow-derived human mesenchymal stem cells. Biotechnol Bioprocess Eng. 2007 Dec 1;12(6):601-9.

24. Kuang $R$, Wang Z, Xu Q, Liu S, Zhang W. Influence of mechanical stimulation on human dermal fibroblasts derived from different body sites. Int J Clin Exp Med. 2015;8(5):7641-7.

25. Xu Y, Dong S, Zhou Q, Mo X, Song L, Hou T, et al. The effect of mechanical stimulation on the maturation of TDSCs-poly(L-lactide-co-e-caprolactone)/collagen scaffold constructs for tendon tissue engineering. Biomaterials. 2014 Mar;35(9):2760-72.

26. Wang $\mathrm{Y}-\mathrm{K}$, Chen CS. Cell adhesion and mechanical stimulation in the regulation of mesenchymal stem cell differentiation. J Cell Mol Med. 2013 Jul;17(7):823-32.

27. Subramony SD, Dargis BR, Castillo M, Azeloglu EU, Tracey MS, Su A, et al. The guidance of stem cell differentiation by substrate alignment and mechanical stimulation. Biomaterials. 2013 Mar;34(8):1942-53.

28. Screen HRC, Shelton JC, Bader DL, Lee DA. Cyclic tensile strain upregulates collagen synthesis in isolated tendon fascicles. Biochem Biophys Res Commun. 2005 Oct 21;336(2):424-9. 
29. Huisman E, Lu A, McCormack RG, Scott A. Enhanced collagen type I synthesis by human tenocytes subjected to periodic in vitro mechanical stimulation. BMC Musculoskelet Disord. 2014 Nov 21;15:386.

30. Wu S, Wang Y, Streubel PN, Duan B. Living nanofiber yarn-based woven biotextiles for tendon tissue engineering using cell tri-culture and mechanical stimulation. Acta Biomater. 2017 15;62:102-15.

31. Heinemeier KM, Kjaer M. In vivo investigation of tendon responses to mechanical loading. J Musculoskelet Neuronal Interact. 2011 Jun;11(2):115-23.

32. Dex S, Alberton P, Willkomm L, Söllradl T, Bago S, Milz S, et al. Tenomodulin is Required for Tendon Endurance Running and Collagen I Fibril Adaptation to Mechanical Load. EBioMedicine. 2017 Jun;20:240-54.

33. Nagasawa K, Noguchi M, Ikoma K, Kubo T. Static and dynamic biomechanical properties of the regenerating rabbit Achilles tendon. Clin Biomech Bristol Avon. 2008 Jul;23(6):832-8.

34. Doroski DM, Brink KS, Temenoff JS. Techniques for biological characterization of tissueengineered tendon and ligament. Biomaterials. 2007 Jan;28(2):187-202.

35. Kubo K, Kanehisa H, Fukunaga T. Effect of stretching training on the viscoelastic properties of human tendon structures in vivo. J Appl Physiol Bethesda Md 1985. 2002 Feb;92(2):595-601.

36. Licup AJ, Münster S, Sharma A, Sheinman M, Jawerth LM, Fabry B, et al. Stress controls the mechanics of collagen networks. Proc Natl Acad Sci U S A. 2015 Aug 4;112(31):9573-8.

37. Martin RB, Ishida J. The relative effects of collagen fiber orientation, porosity, density, and mineralization on bone strength. J Biomech. 1989;22(5):419-26.

\section{Author contributions}

A.G.G conceived, designed and performed the experiments. J.B.P developed the mechanical data analysis and assisted with in vitro mechanical stimulation. M.B.L was involved with cell culture maintain. S.L.R and M.N provided support and information regarding cell extraction. Q.D provided technical support with Bose BioDynamic 5100. C.L and F.B provides scientific directions and analysis of the data. A.G.G, C.L and F.B wrote the manuscript. 
606 Competing interests

607 The authors declare no competing interests.

608

609 Figure legends

610 Figure 1. Electrospinning device.

611 Figure2. Experimental plan design. Correlation between cellular activity (Cell Scale T6) and 612 biomechanical performance (Bose Biodynamic 5100).

613 Figure3. SEM pictograph of a 10-wt \% PCL scaffold (A). Fibre orientation distribution in PCL 614 scaffolds (B).

615 Figure 4. Stress (MPa) vs strain (\%) curve for 10-wt \% PCL scaffolds in a dry (dark grey) or 616 wet (light grey) state, obtained using the Electroforce 3200 system.

617 Figure 5. Cell proliferation (\#) and hydroxyproline synthesis (§) over time, at 1 and 2 weeks 618 of

619 static and dynamic culture performed with T6 CellScale. Hydroxyproline concentration was 620 related to collagen content $(* * *$ for $p<0.001) .\left(^{*}\right)$ Fluorescence staining of the actin 621 cytoskeleton (red) (A-D), type-1 collagen (green) (E-F) and tendomodulin (I-L) for static or 622 dynamic culture performed for 1 or 2 weeks). Cell nuclei were stained blue as a counter623 stain.

624 Scale bar of $50 \mu \mathrm{m}$.

625 Figure 6. Design of the dynamic culture process during 12 days of stimulation (A). 626 Representative stress vs strain curve (B) of the first sinus from the first cycle and the last 627 sinus from the last cycle for cell-constructs subjected to dynamic culture conditions.

628 Figure 7. Tan $\delta$, Energy dissipation values, $E^{*}, E^{\prime}$ and $E^{\prime \prime}$ for both dynamic and static 629 conditions cultured with or without cells for both days 2 and 14 . Tests were performed in 630 the Bose BioDynamic 5100. Values represent the arithmetic average for each value from 6311200 to 3600 sinuses $(n=3)$. There was no statistical difference between the conditions.

632 Figure 8. Evolution of the Tan $\delta(\mathbf{A})$, dissipated energy (B), $E^{\prime}(\mathbf{C})$ and $E^{\prime \prime}(\mathbf{D})$ over time 633 expressed in terms of variation (V\%). V\%= ((Last cycle - First cycle) / (First cycle) $) * 100$.

634 Figure 9. Schematic representation of evolution in the mechanical properties for cellular 635 constructions in the absence or presence of mechanical stimulation. 
636

637

638

639

640

641

642

643

644

645

646

647

648

649

650

651

652

653

John Wiley \& Sons, Inc. 


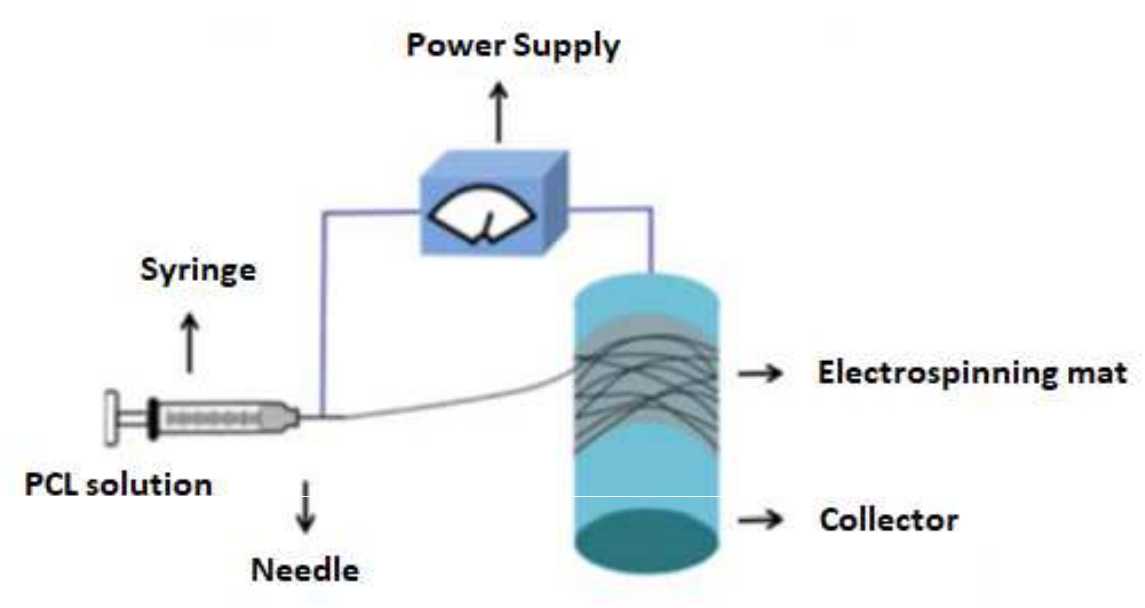

Figure 1. Electrospinning device. 


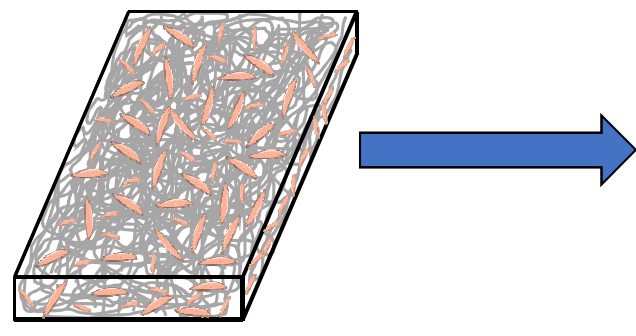

2 days static culture: $10^{\wedge} 4$ cells $/ \mathrm{cm}^{2}$

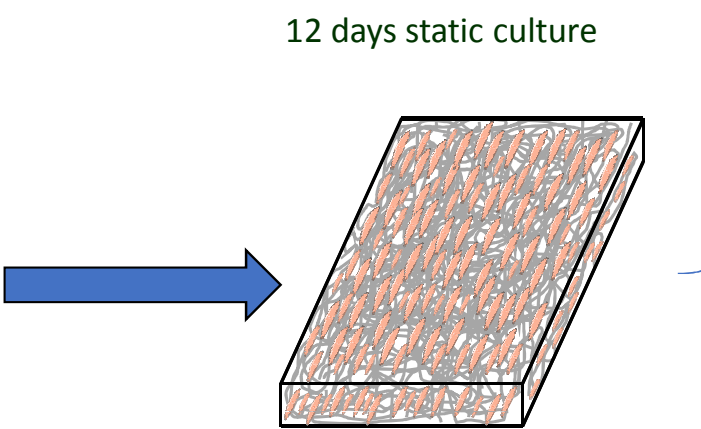

CellScale T6 Bioreactor

12 days dynamic culture

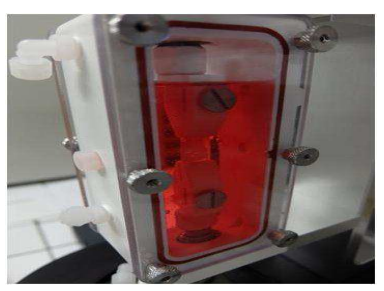

Bose BioDynamic 5100

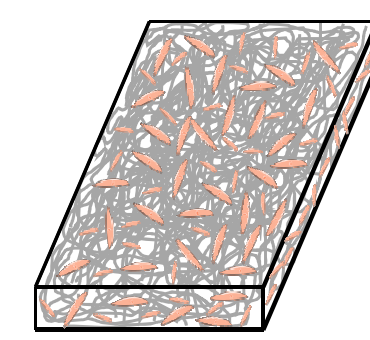

-Proliferation

-Morphology: Rhodamine/Phallodine.

-ECM synthesis: Col and TNMD.

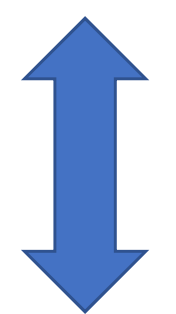

\section{Correlation}

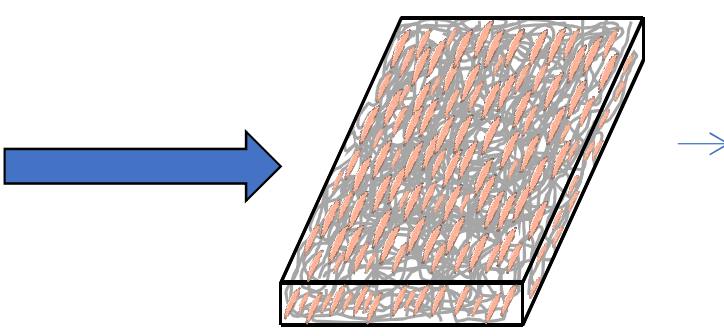

12 days dynamic culture Dissipation, E', E', E*
Biomechanical analysis: $\operatorname{Tan}^{\delta}$, Energy
Figure 2. Experimental plan design. Correlation between cellular activity (Cell Scale T6) and biomechanical performance (Bose Biodynamic 5100). Briefly, after 2 days of static culture, scaffolds were transferred to the different bioreactors (Electro Force and Bose Biodynamic). Once attached, the dynamic culture was launched for 2 weeks. 

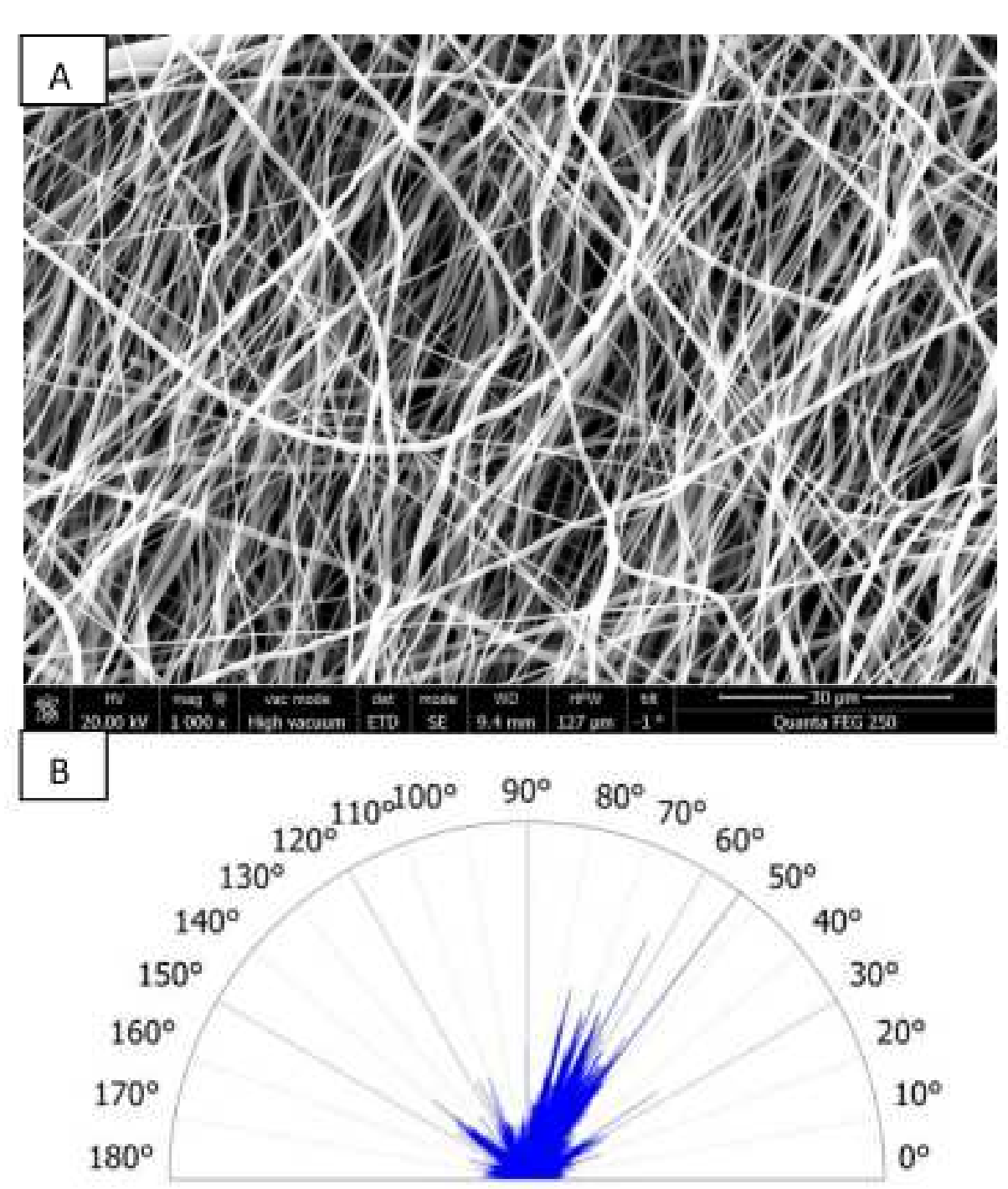

Figure 3. SEM pictograph of a 10wt \% PCL scaffold (A). Fibre orientation distribution in $\mathrm{PCL}$ scaffolds (B). 


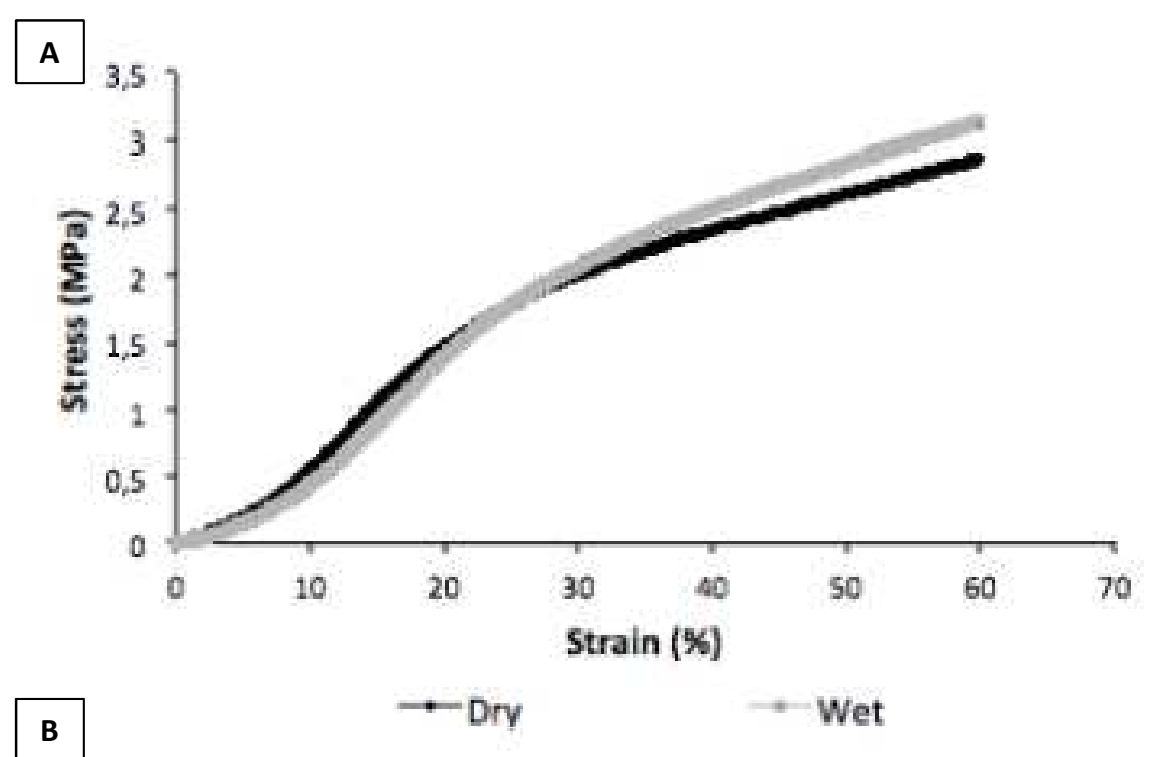

Figure 4. Stress (MPa) vs strain (\%) curve for 10 -wt \% PCL scaffolds in a dry (dark grey) or wet (light grey) state, obtained using the Electroforce 3200 system.

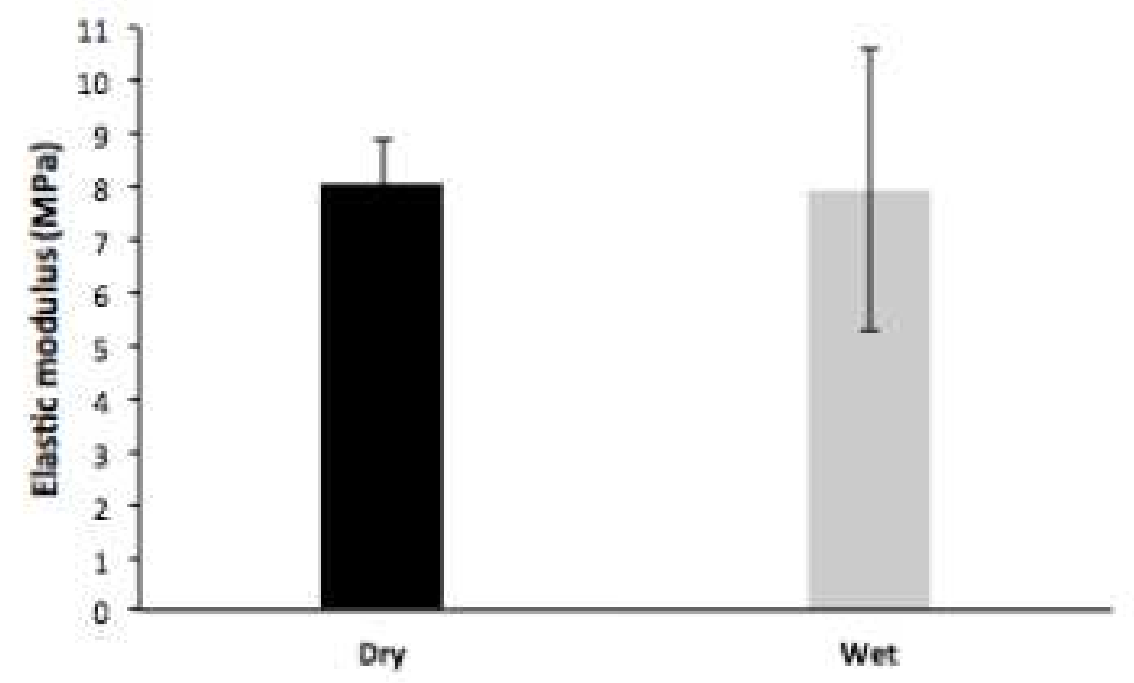




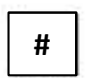

$\S$

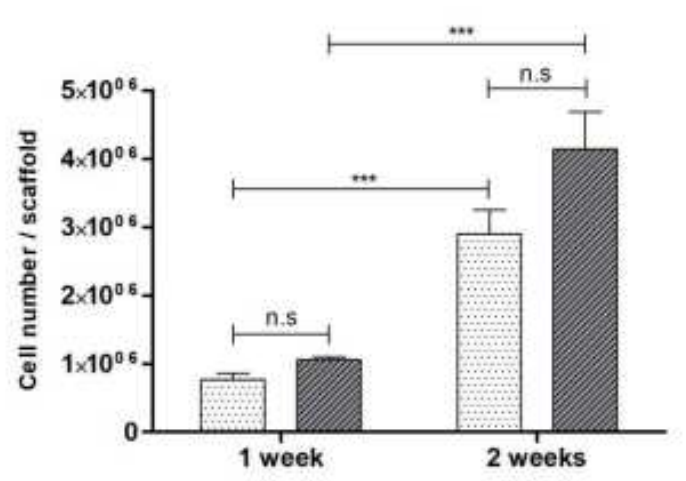

$$
\square \text { Static }
$$

Dynamic

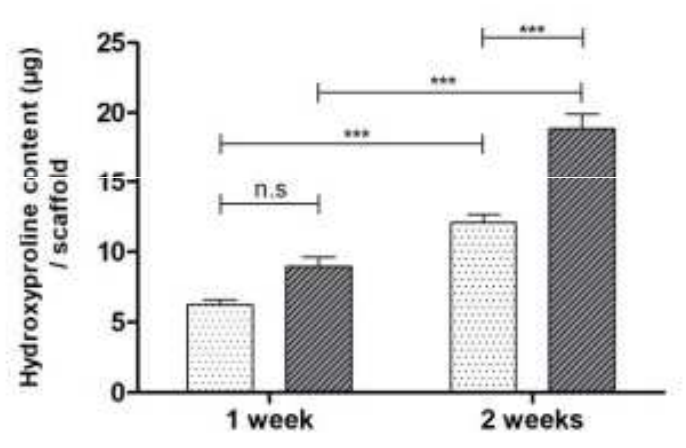

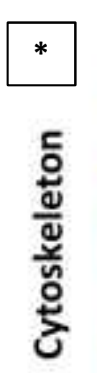

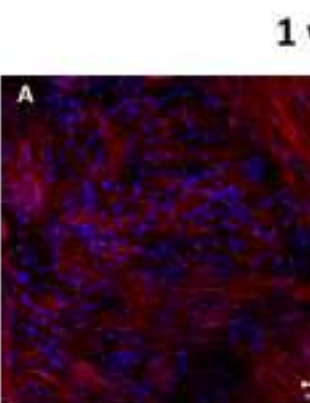

1 week
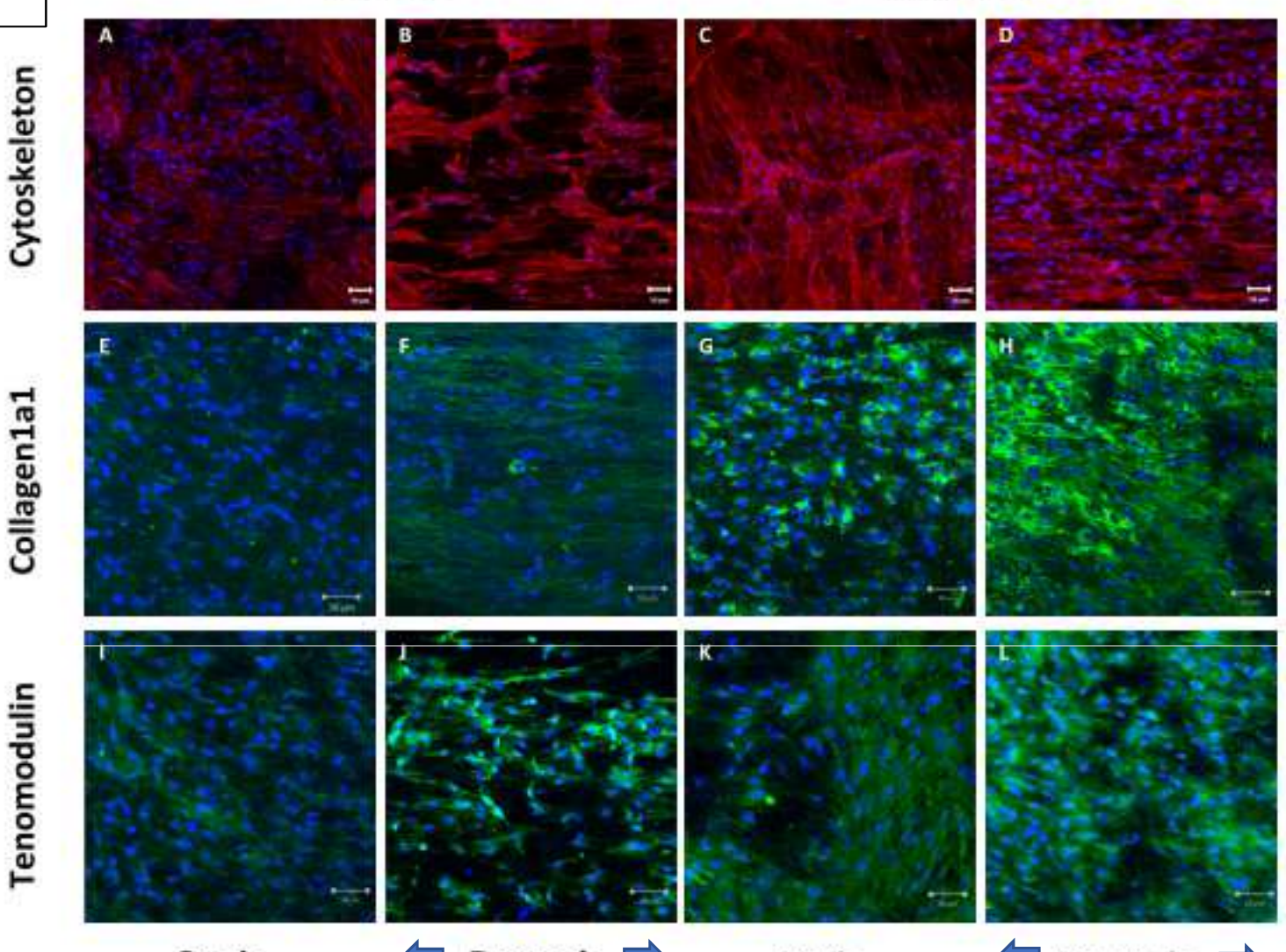

Static

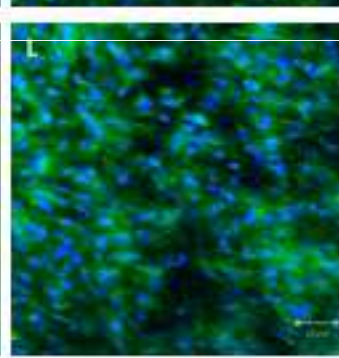

Dynamic

32 Figure 5. Cell proliferation (\#) and hydroxyproline synthesis ( $\$$ ) over time, at 1 and 2 weeks of 34 static and dynamic culture performed with T6 CellScale. Hydroxyproline concentration was ${ }_{36}^{35}$ related to collagen content $(* * *$ for $p<0.001)$. $\left({ }^{*}\right)$ Fluorescence staining of the actin 37 cytoskeleton (red) (A-D), type-1 collagen (green) (E-F) and tendomodulin (I-L) for static or ${ }_{39}^{38}$ dynamic culture performed for 1 or 2 weeks). Cell nuclei were stained blue as a counter-stain. ${ }^{40}$ Scale bar of $50 \mu \mathrm{m}$. Blue arrows indicate the sense of the stretch. 

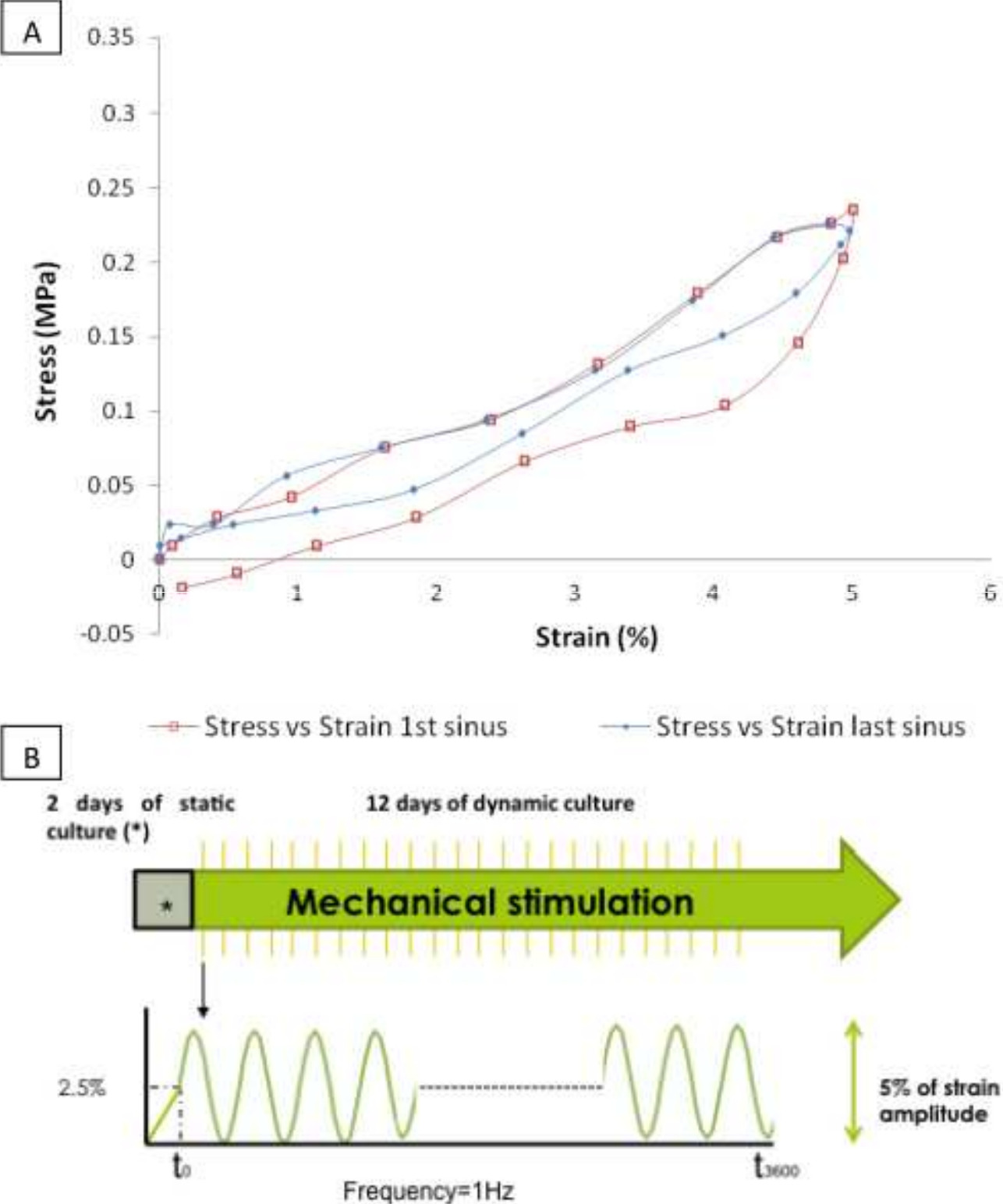

Figure 6. Design of the dynamic culture process during 12 days of stimulation (A). Representative stress vs strain curve (B) of the first sinus from the first cycle and the last sinus from the last cycle for cell-constructs subjected to dynamic culture conditions.

After 2 days of static culture, the cell-construct or the control scaffolds were fixed inside the bioreactor chamber and the mechanical test was launched. Both signal force and displacement were recorded over time and found to be smooth, without any background noise, making it possible to monitor mechanical (elastic and viscoelastic) properties. 


\begin{tabular}{|c|c|c|c|c|c|c|c|c|c|c|}
\hline & \multicolumn{2}{|c|}{ Tan delta } & \multicolumn{2}{|c|}{ Hysteresis } & \multicolumn{2}{|c|}{$\mathrm{E}^{*}(\mathrm{MPa})$} & \multicolumn{2}{|c|}{$E^{\prime}(\mathrm{MPa})$} & \multicolumn{2}{|c|}{$E^{\prime \prime}(\mathrm{MPa})$} \\
\hline & $\begin{array}{c}2 \\
\text { days }\end{array}$ & $\begin{array}{c}14 \\
\text { days }\end{array}$ & $\begin{array}{c}2 \\
\text { days }\end{array}$ & $\begin{array}{c}14 \\
\text { days }\end{array}$ & $\begin{array}{c}2 \\
\text { days }\end{array}$ & $\begin{array}{c}14 \\
\text { days }\end{array}$ & $\begin{array}{c}2 \\
\text { days }\end{array}$ & $\begin{array}{c}14 \\
\text { days }\end{array}$ & $\begin{array}{c}2 \\
\text { days }\end{array}$ & $\begin{array}{c}14 \\
\text { days }\end{array}$ \\
\hline $\begin{array}{l}\text { Static with } \\
\text { cells }\end{array}$ & $\begin{array}{l}0.08 \pm \\
0.01\end{array}$ & $\begin{array}{l}0.10 \pm \\
0.01\end{array}$ & $\begin{array}{l}0.64 \pm \\
0.35\end{array}$ & $\begin{array}{l}0.80 \pm \\
0.14\end{array}$ & $\begin{array}{l}3.97 \pm \\
2.27\end{array}$ & $\begin{array}{l}4.27 \pm \\
0.79\end{array}$ & $\begin{array}{l}3.95 \pm \\
2.26\end{array}$ & $\begin{array}{l}4.24 \pm \\
0.78\end{array}$ & $\begin{array}{l}0.30 \pm \\
0.16\end{array}$ & $\begin{array}{l}0.44 \pm \\
0.08\end{array}$ \\
\hline Static control & $\begin{array}{l}0.12 \pm \\
0.03\end{array}$ & $\begin{array}{l}0.12 \pm \\
0.02\end{array}$ & $\begin{array}{l}0.92 \pm \\
0.14\end{array}$ & $\begin{array}{l}0.81 \pm \\
0.11\end{array}$ & $\begin{array}{l}4.03 \pm \\
0.92\end{array}$ & $\begin{array}{l}3.46 \pm \\
0.43\end{array}$ & $\begin{array}{l}3.90 \pm \\
0.91\end{array}$ & $\begin{array}{l}3.42 \pm \\
0.43\end{array}$ & $\begin{array}{l}0.42 \pm \\
0.07\end{array}$ & $\begin{array}{l}0.38 \pm \\
0.06\end{array}$ \\
\hline $\begin{array}{l}\text { Dynamic with } \\
\text { cells }\end{array}$ & $\begin{array}{l}0.09 \pm \\
0.01\end{array}$ & $\begin{array}{l}0.10 \pm \\
0.06\end{array}$ & $\begin{array}{l}0.90 \pm \\
0.11\end{array}$ & $\begin{array}{l}1.02 \pm \\
0.12\end{array}$ & $\begin{array}{l}4.34 \pm \\
1.21\end{array}$ & $\begin{array}{l}5.07 \pm \\
0.11\end{array}$ & $\begin{array}{l}4.32 \pm \\
1.20\end{array}$ & $\begin{array}{l}5.04 \pm \\
0.11\end{array}$ & $\begin{array}{l}0.37 \pm \\
0.13\end{array}$ & $\begin{array}{l}0.49 \pm \\
0.02\end{array}$ \\
\hline $\begin{array}{l}\text { Dynamic } \\
\text { control }\end{array}$ & $\begin{array}{l}0.09 \pm \\
0.03\end{array}$ & $\begin{array}{l}0.09 \pm \\
0.03\end{array}$ & $\begin{array}{l}1.47 \pm \\
0.57\end{array}$ & $\begin{array}{l}1.32 \pm \\
0.48\end{array}$ & $\begin{array}{l}6.68 \pm \\
0.87\end{array}$ & $\begin{array}{l}6.24 \pm \\
0.83\end{array}$ & $\begin{array}{l}6.63 \pm \\
0.89\end{array}$ & $\begin{array}{l}6.21 \pm \\
0.84\end{array}$ & $\begin{array}{l}0.59 \pm \\
0.14\end{array}$ & $\begin{array}{l}0.53 \pm \\
0.10\end{array}$ \\
\hline
\end{tabular}

Figure 7. Tan $\delta$, Energy dissipation values, $E^{*}, E^{\prime}$ and $E^{\prime \prime}$ for both dynamic and static conditions cultured with or without cells for both days 2 and 14. Tests were performed in the Bose BioDynamic 5100. Values represent the arithmetic average for each value from 1200 to 3600 sinuses $(n=3)$. There was no statistical difference between the conditions. 

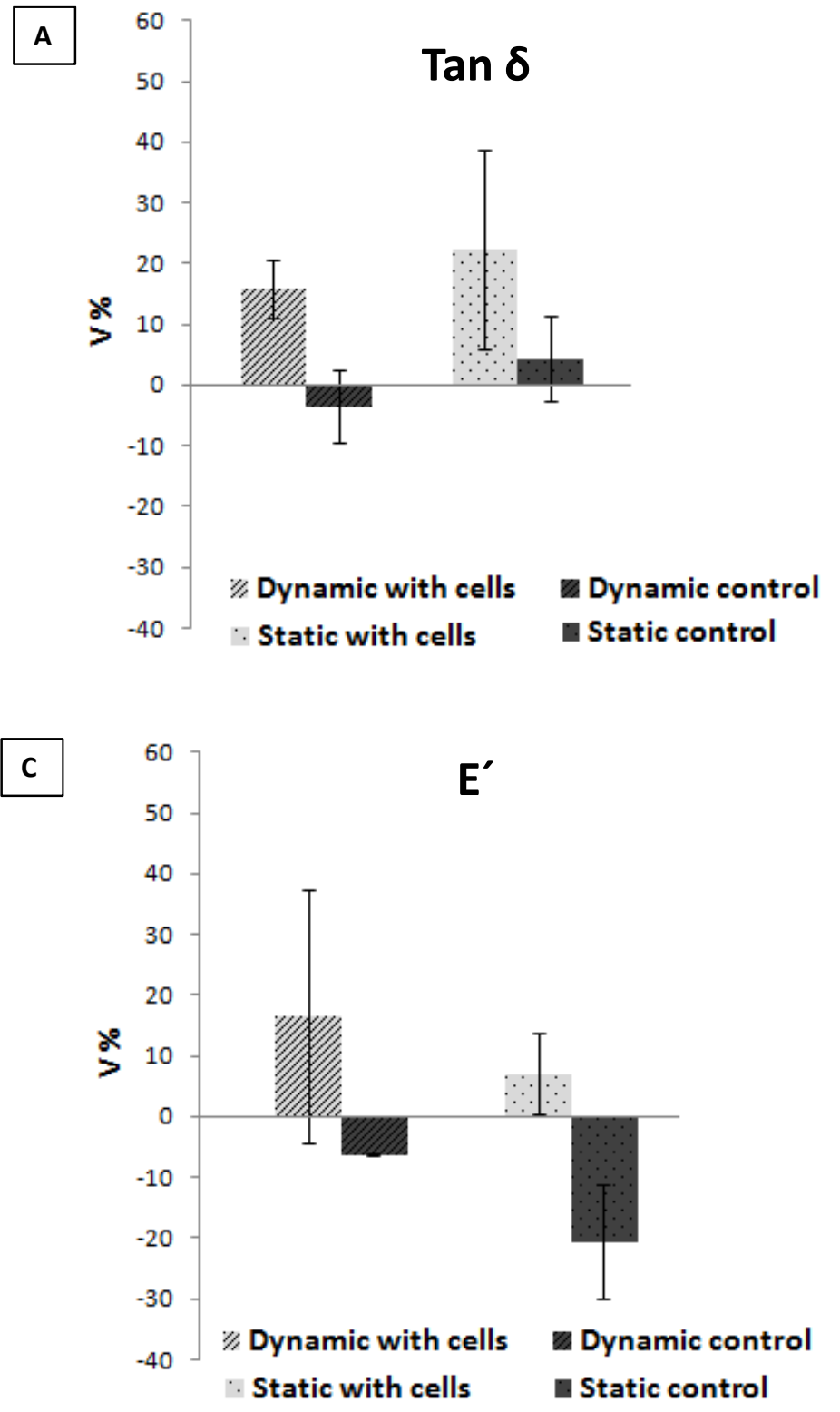
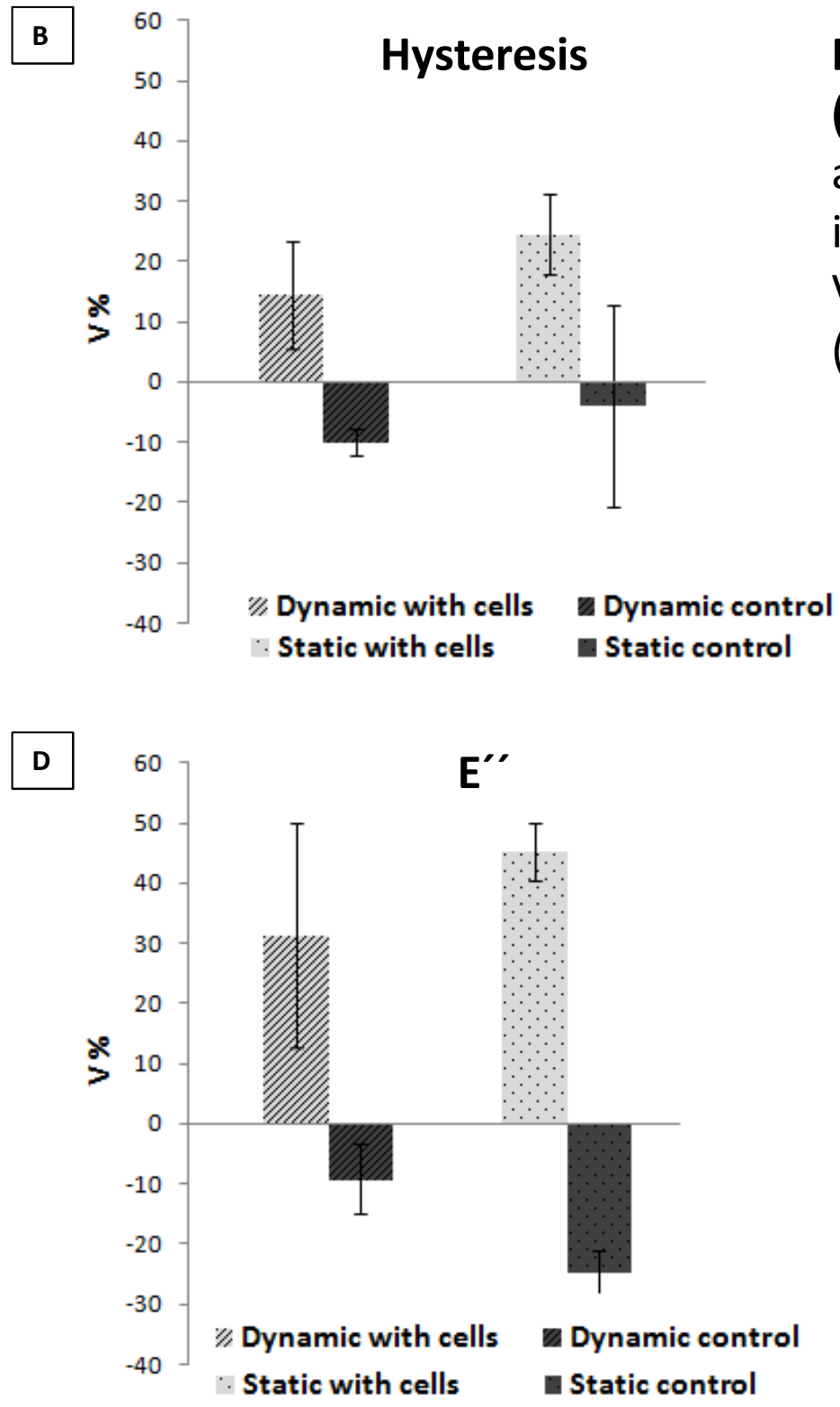

Figure 8. Evolution of the $\operatorname{Tan} \delta$ (A), dissipated energy (B), E'(C) and $E^{\prime \prime}(D)$ over time expressed in terms of variation (V\%). V\% $=(($ Last cycle - First cycle $) /$ (First cycle))*100 
